Barbara Lisiecka - Agata Dudek - Robert Ulewicz

\title{
ATMOSPHERIC PLASMA SPRAVING (APS) AND ALLOVING AS METHODS TO MODIFY PROPERTIES OF THE SSS SURFACE LAYERS
}

Use of the powder metallurgy (PM) in production of various components has been growing in the automotive industry, including production of sintered stainless steels (SSSs). This study aims to improve the functional properties of SSSs by formation of the Cr3C2-NiCr coating by APS method. The next stage involved alloying of the surface of SSSs using the gas tungsten arc welding (GTAW). Analysis of microstructures was carried out using microscopy (metallographic microscope and scanning electron microscope). Furthermore, the study presents XRD (X-ray powder diffraction) examinations, mechanical properties and surface roughness measurements. The presented modification improved properties of the surface layers examined in the study and enabled a reduction in the wall thickness of the detail, which is important factor in the automotive and transport industry.

Keywords: (SSS) steel, Cr3C2-NiCr coating, APS, GTAW, surface layer alloying

\section{Introduction}

Due to the wear observed during use, the surface of the solid body has been a subject of the frequent tests. This surface can be repeatedly modified in physical and chemical terms, which results in obtaining the desired functional properties that are better than the properties of the native material [1-3]. The surface layer alone plays mostly a technical role. It has to show very high requirements for increased durability of consumable machine parts and tools designed and intended for operation in the conditions of friction and fatigue. Appropriate surface modification has a significant impact on functional properties (e.g. significant extension of the durability of tools, machine parts and devices, especially in terms of tribological properties) and the final use of objects and finished products [4-6]. Duplex steels are increasingly used in the automotive industry for catalyst housing components, turbochargers and rotors [7]. They are also susceptible to automation of production processes [8].

The coating application and surface treatments have been among the methods that are the most commonly used to improve the surface properties of SSSs. The creation of the coating increases, among others, the surface resistance to oxidation or abrasion. The mechanical properties of the coating, e.g. interfacial adhesion and fracture behaviours, can be criteria when choosing a coating for a given application [7-11]. Creation of the transition metal carbides based coatings is a very interesting and well-known modification. Transition metal carbides are characterized by a very high melting point, hardness and strength at high temperatures. Furthermore, they show improved properties related to electrical and thermal conductivity, which ensures that they are widely used in metallurgy. Due to their high strength at high temperatures compared to other carbides, chromium carbides are the most often used in surface modification [12-15].

Chromium carbides can occur in three polymorphic structures: cubic $\left(\mathrm{Cr}_{23} \mathrm{C}_{6}\right)$, hexagonal $\left(\mathrm{Cr}_{7} \mathrm{C}_{3}\right)$ and orthorhombic $\left(\mathrm{Cr}_{3} \mathrm{C}_{2}\right)$. Considering the appropriate adhesion to the substrate and the best mechanical properties (e.g. higher hardness, wear resistance and strength, high melting point, high elastic modulus, great chemical corrosion resistance), chromium carbide $\left(\mathrm{Cr}_{3} \mathrm{C}_{2}\right)$ is the most frequently chosen for the surface modification through deposition of coatings. Nowadays, chromium carbide coatings have been known to improve resistance to high-temperature oxidation (up to $750^{\circ} \mathrm{C}$ ) and prevent the coating properties from deterioration, which is related to formation of the $\mathrm{Cr}_{2} \mathrm{O}_{3}$ layer on its surface [16-17]. Thermal spraying of $\mathrm{Cr}_{3} \mathrm{C}_{2}$ $\mathrm{NiCr}$ is successfully used for protecting and modification of the surface in the aerospace, automobile or energy sectors. Among the methods used to obtain the $\mathrm{Cr}_{3} \mathrm{C}_{2}-\mathrm{NiCr}$ coatings are such methods like electron beam physical vapour deposition (EB-PVD), atmospheric plasma spraying (APS) and high-velocity oxy-fuel (HVOF) [18-21].

Atmospheric plasma spraying (APS) continues to attract much interest and is successfully used to deposit chromium carbide coatings. As is known, the deposition of powders as dense and homogeneous coatings is possible using the thermal spraying using the APS method. In this process, the powder of $\mathrm{Cr}_{3} \mathrm{C}_{2}-\mathrm{NiCr}$ is introduced into the plasma jet and heated to a molten state. Then, the heated material is propelled towards a native material. The result

\footnotetext{
Barbara Lisiecka ${ }^{1, *}$, Agata Dudek ${ }^{1}$, Robert Ulewicz ${ }^{2}$

${ }^{1}$ Department of Material Engineering, Faculty of Production Engineering and Materials Technology, Czestochowa University of Technology, Poland

${ }^{2}$ Department of Production Engineering and Safety, Faculty of Management, Czestochowa University of Technology, Poland

*E-mail of corresponding author: lisiecka.barbara@wip.pcz.pl
} 


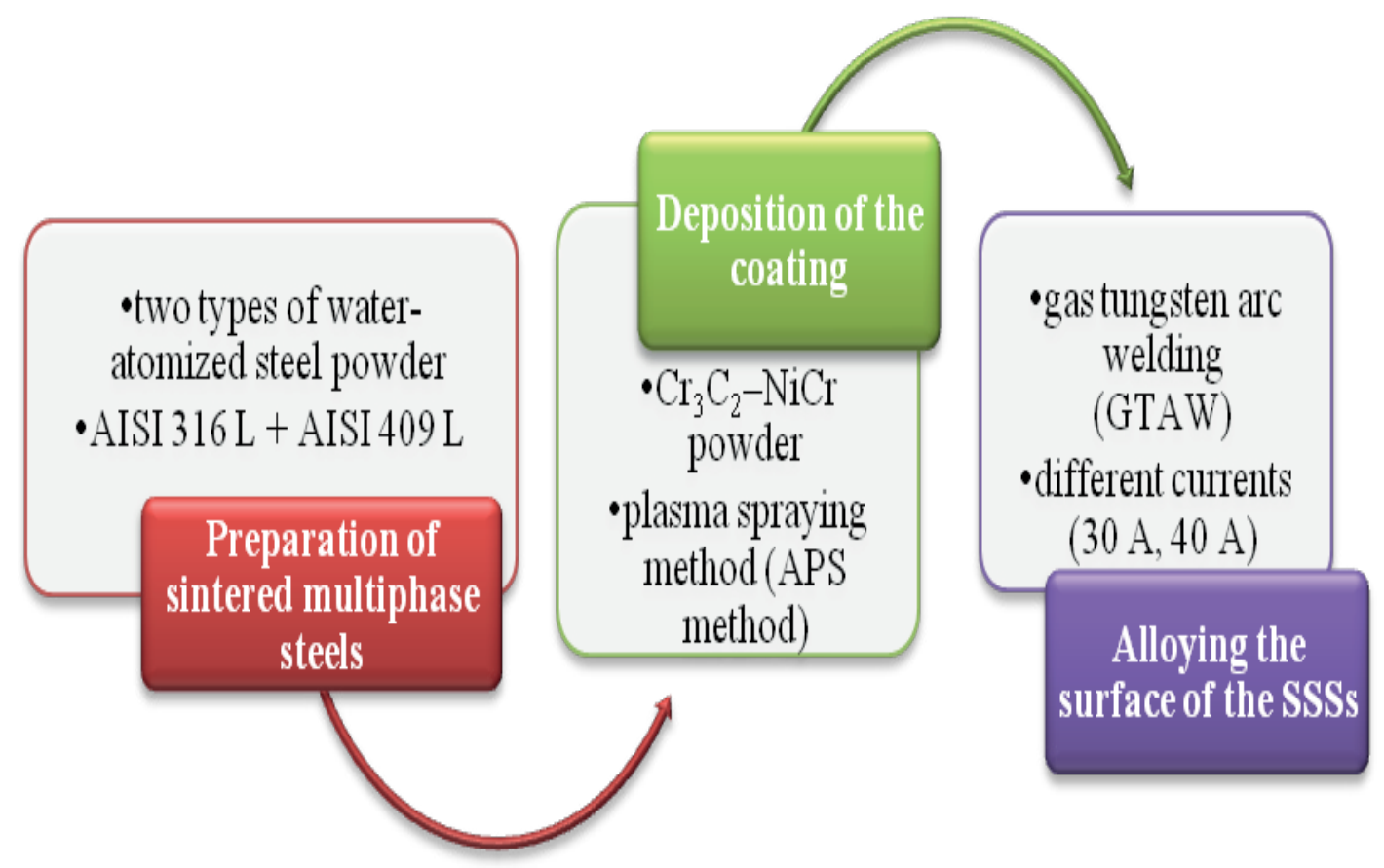

Figure 1 The purpose of research

Table 1 Elements contained in powders studied (\% wt.)

\begin{tabular}{ccccccccc}
\hline Powder grade & $\mathrm{Cr}$ & $\mathrm{Ni}$ & $\mathrm{Mo}$ & $\mathrm{Si}$ & $\mathrm{Mn}$ & $\mathrm{C}$ & $\mathrm{S}$ & $\mathrm{Fe}$ \\
\hline AISI 316L & 16.80 & 12.00 & 2.00 & 0.90 & 0.10 & 0.022 & 0.005 & Balance \\
AISI 409L & 11.86 & 0.14 & 0.02 & 0.82 & 0.14 & 0.020 & 0.010 & Balance \\
\hline
\end{tabular}

Table 2 Proportion of individual powders used to make the series of samples (\% wt.)

\begin{tabular}{ccc}
\hline \multirow{2}{*}{ Series of samples } & \multicolumn{2}{c}{ Powder grade } \\
\cline { 2 - 3 } & AISI 316L & AISI 409L \\
\hline 1 & $80 \%$ & $20 \%$ \\
2 & $50 \%$ & $50 \%$ \\
3 & $20 \%$ & $80 \%$ \\
\hline
\end{tabular}

Table 3 Sinters forming parameters

\begin{tabular}{cc}
\hline Parameters & Description/values \\
\hline Compact & uniaxially \\
Lubricant & $1 \%$ Acrawax C \\
Pressing pressure & $720 \mathrm{MPa}$ \\
Sintering temperature & $1250^{\circ} \mathrm{C}$ \\
Sintering time & 30 minutes \\
Cooling rate & $0.5^{\circ} \mathrm{C} / \mathrm{s}$ \\
\hline
\end{tabular}

is a coating formed from adhering powder particles. The metallurgical properties do not change after the deposition of the coating (no regular heating). Plasma spray coatings are extremely interesting in terms of their capability of giving specific properties (e.g. porosity, roughness)[22-27].

The welding techniques that are based on concentrated thermal energy are increasingly used to modify the surface of the SSSs. One of the most widespread and interesting methods in surface processing with alloys are laser technologies. As laser technologies are expensive, alternative technologies are increasingly being sought. The GTAW method offers a great alternative here, and it is very commonly used to modify surface layers, including the SSSs surfaces described here. The GTAW method is easy to use and is characterized by a low cost equipment. Furthermore, use of the GTAW method allows the functional properties of the surface to be modified [28-32]. 
Table 4 APS process parameters

\begin{tabular}{cc}
\hline Parameters & Ranges \\
\hline Voltage $\left(\mathrm{U}_{\mathrm{r}}\right)$ & $50(\mathrm{~V})$ \\
Current intensity $\left(\mathrm{I}_{\mathrm{r}}\right)$ & $45(\mathrm{~A})$ \\
Spray distance & $120(\mathrm{~mm})$ \\
Primary plasma gas Ar & $\sim 45(\mathrm{l} / \mathrm{min})$ \\
Secondary plasma gas $\mathrm{H}_{2}$ & $\sim 12(\mathrm{l} / \mathrm{min})$ \\
\hline
\end{tabular}

Table 5 X-ray diffractometer parameters

\begin{tabular}{cc}
\hline Parameters & Ranges \\
\hline Angle range $(2 \theta)$ & $10-120^{\circ}$ \\
Tube voltage $\left(\mathrm{U}_{\mathrm{r}}\right)$ & $40(\mathrm{kV})$ \\
Tube current $(\mathrm{I})$ & $40(\mathrm{~mA})$ \\
Step-scan mode & $0.1^{\circ}$ \\
Step size & $0.1^{\circ}$ \\
Pulse integration time $\left(\mathrm{t}_{\mathrm{r}}\right)$ & $10(\mathrm{~s})$ \\
\hline
\end{tabular}

The authors of the present study proposed to improve functional properties, mainly hardness and wear resistance. Several modifications were made and the purpose of the research is shown in Figure 1.

\section{Experimental}

Preparation of the multiphase sinters, used for examinations, was described in detail in the paper [33] Table 1 shows the contents of individual elements in the powders used to obtain sinters. The nominal particle size of both powders is $130-150 \mu \mathrm{m}$.

Three different sinters were used in examinations, formed by mixing the two powders in different proportions (i.e. austenite and ferrite). Three series of samples were obtained (see Table 2).

Table 3 presents parameters affecting the production of sintered samples. To reduce oxidation of the batch and to protect it from a decline in chromium concentration, the process was performed in the reduction atmosphere using $100 \%$ hydrogen

The next stage of examinations consisted of modification of the surface layer by deposition of a coating using the plasma spraying (APS method). To improve the functional properties of the analysed steels, it was decided to deposit a chromium carbide coating. To prepare a suitable powder mixture for the coating, the chromium carbide was mixed mechanically, at a ratio of $75 \%$ wt. $\mathrm{Cr}_{3} \mathrm{C}_{2}$ and $25 \%$ wt. NiCr. Table 4 presents parameters of the coating spraying process. A $60 \mu \mathrm{m}$ coating was obtained as a result of the modifications.

Gas tungsten arc welding (GTAW) has been used for surface layer treatment, used for the coatings of sintered stainless steels. Alloying of sintered stainless steels was performed at a constant surface scanning rate of $340 \mathrm{~mm} /$ min and welding at a current intensity of $30 \mathrm{~A}$ and $40 \mathrm{~A}$ and voltage parameters. Argon was used in the process as a shielding gas. Its flow rate was set at $\sim 14 \mathrm{l} / \mathrm{min}$.
The stereo microscope Olympus SZ61 has been used for the macroscopic evaluation of sintered stainless steels after application of $\mathrm{Cr}_{3} \mathrm{C}_{2}-\mathrm{NiCr}$ powder and after the surface alloying process. Analysis of the microstructure was performed using microscopy (i.e. an Olympus GX41 metallographic microscope and a JSM-6610LV scanning electron microscope Jeol). Analysis of the chemical composition was carried out using a Jeol JSM-6610LV scanning electron microscope. The microhardness measurements for the SSSs were carried out using the Vickers method under a load of $980.7 \mathrm{mN}$.

The X-ray Seifert 3003 T-T diffractometer, with a cobalt lamp $\lambda_{\text {cok }}=0.17902 \mathrm{~nm}$, was used for identification of the phase composition of the alloyed surface of specimens. All the measurement parameters are presented in Table 5.

A Hommel T1000 contact profilometer was used to evaluate roughness parameters $\left(R_{a}, R_{z}, R_{\max }\right)$ on the surface of samples. Three measurements were made, with each measurement consisting of the contact of a stylus with the analysed surface, using a differential measuring system.

The scratch resistance test (Revetest XPress Plus with Rockwell indenter) was used to evaluate the coefficient of friction. Measurements consisted of the mechanically induced damage to the surface obtained by scratching. A constant load of $10 \mathrm{~N}$, scratch length of $5 \mathrm{~mm}$ and the scratch velocity of $5 \mathrm{~mm} / \mathrm{min}$ were used. The main purpose of the scratch test was to determine the relationship between the direction of the scratch and the surface orientation depending on the penetration depth and to evaluate the coefficient of friction.

\section{Results and discussion}

The $\mathrm{Cr}_{3} \mathrm{C}_{2}-\mathrm{NiCr}$ powder used for spraying and deposition of the coating is shown in Figure 2.

Figure 3 presents the microstructure of the surface of the coating (before the alloying process) recorded using scanning electron microscopy. 


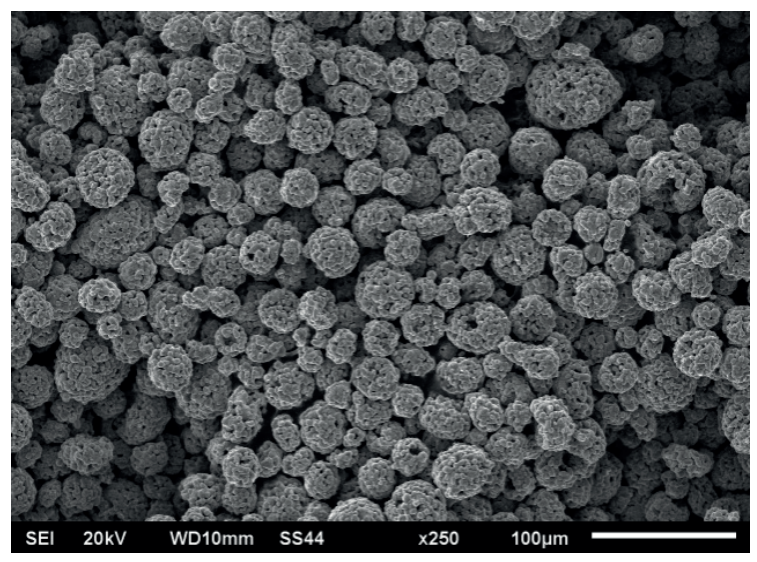

Figure 2 Grains of the $\mathrm{Cr}_{3} \mathrm{C}_{2}-\mathrm{NiCr}$ powder

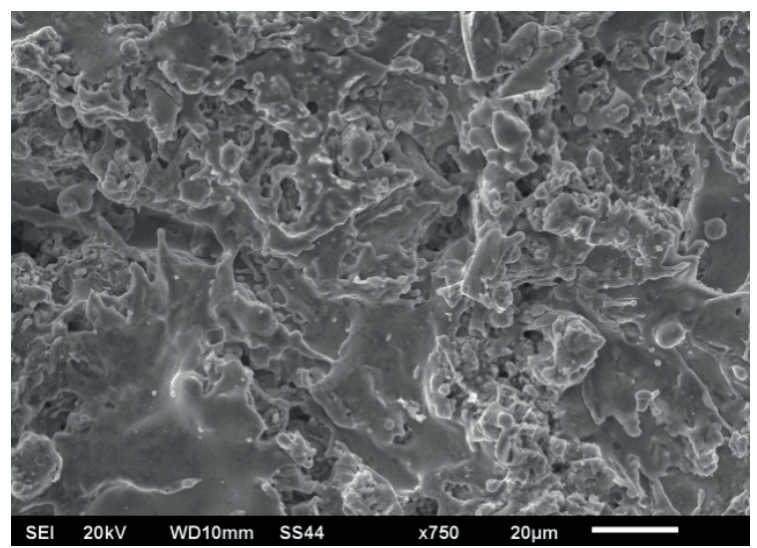

Figure 3 SEM image of the coating deposited on SSS after APS

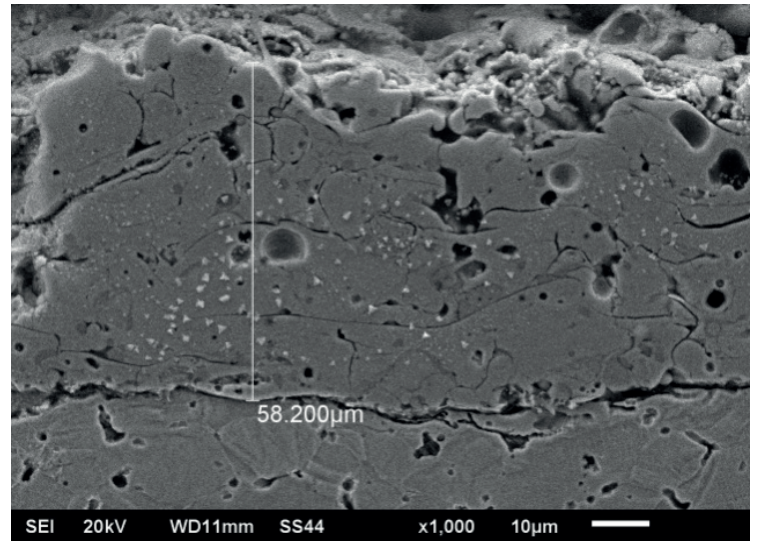

Figure 4 SEM image of the coating after APS

The cross-section of the $\mathrm{Cr}_{3} \mathrm{C}_{2}$ - $\mathrm{NiCr}$ coating obtained using the scanning electron microscope is presented in Figure 4. Thickness of the obtained $\mathrm{Cr}_{3} \mathrm{C}_{2}-\mathrm{NiCr}$ coating was also marked (cca. $60 \mu \mathrm{m}$ ).

The resulting $\mathrm{Cr}_{3} \mathrm{C}_{2}-\mathrm{NiCr}$ coating is characterized by structural elements that are typical for this deposition method (APS). This coating exhibits a porous lamellar structure with visible cracks and particles that have not melted.

After the surface treatment, the macroscopic examinations were performed to assess the effect of alloying on quality of the steel surface. The main criteria
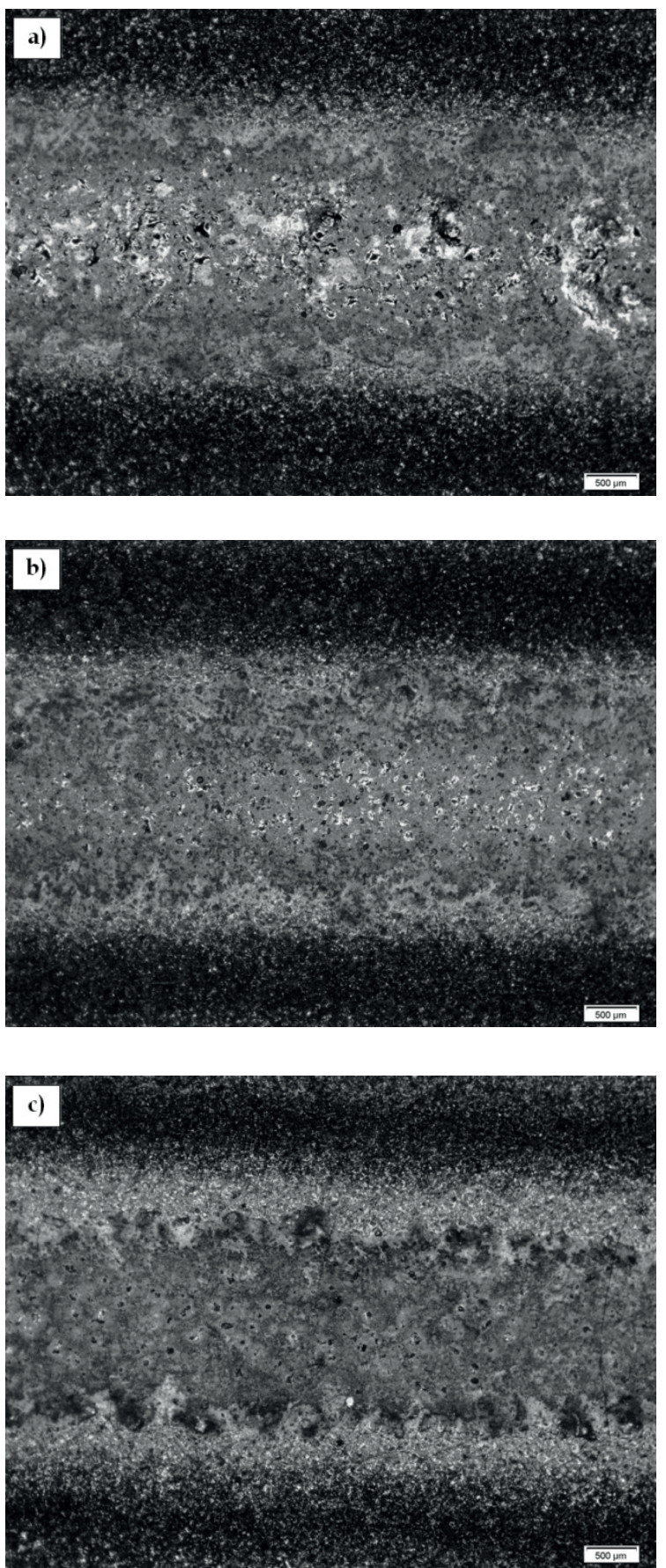

Figure 5 Images of the surface of the SSSs after alloying at 30 A for samples: a) 1, b) 2, c) 3

of evaluation were the continuity of the band, similar width and a relatively smooth surface that did not contain any craters. Figure 5 presents images of the surface after alloying of the SSSs at current intensity $30 \mathrm{~A}$ obtained using an Olympus SZ61 microscope.

The metallographic sections were prepared by etching with a mixture of nitric acid and hydrochloric acid (i.e. aqua regia). Figure 6 shows an image of the microstructure obtained for sample 1 after the surface alloying at 40 A using the metallographic microscope Olympus GX41.

The microstructure analysis confirmed the presence of a homogeneous cellular-dendritic structure resulting 


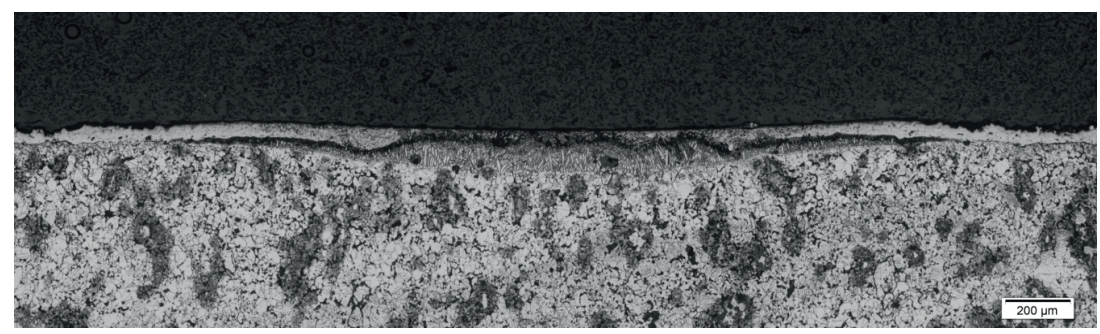

Figure 6 Cross-section of the alloyed zone (sample 1 afteralloying at 40 A)

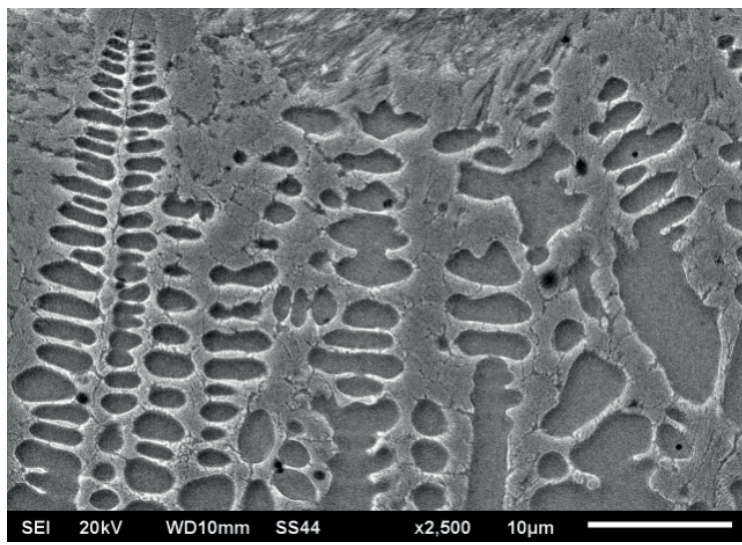

Figure 7 Image showing the alloyed zone (sample 2 after alloying $40 \mathrm{~A}$ )

Table 6 EDX-analysis after alloying at a current intensity of 30 A (AZ-alloying zone, HAZ- heat affected zone, NM-native material)

\begin{tabular}{|c|c|c|c|c|}
\hline \multirow{2}{*}{$\begin{array}{l}\text { Series of } \\
\text { samples }\end{array}$} & \multirow{2}{*}{ Element } & \multicolumn{3}{|c|}{ Weight (\%) } \\
\hline & & $\mathrm{AZ}$ & HAZ & NM \\
\hline \multirow{6}{*}{1} & $\mathrm{Cr}$ & 48.27 & 22.22 & 17.26 \\
\hline & $\mathrm{Ni}$ & 6.97 & 8.33 & 11.87 \\
\hline & Mo & 1.47 & 2.41 & 2.27 \\
\hline & $\mathrm{Fe}$ & 29.05 & 53.34 & 67.78 \\
\hline & $\mathrm{Si}$ & 0.38 & 0.58 & 0.83 \\
\hline & $\mathrm{C}$ & 13.49 & 13.12 & - \\
\hline \multirow{6}{*}{2} & $\mathrm{Cr}$ & 32.09 & 20.45 & 14.86 \\
\hline & $\mathrm{Ni}$ & 8.00 & 7.55 & 5.43 \\
\hline & Mo & 1.22 & 0.69 & 0.95 \\
\hline & $\mathrm{Fe}$ & 46.29 & 65.79 & 77.24 \\
\hline & $\mathrm{Si}$ & 0.52 & 0.79 & 1.52 \\
\hline & $\mathrm{C}$ & 11.89 & 4.72 & - \\
\hline \multirow{6}{*}{3} & $\mathrm{Cr}$ & 74.94 & 28.52 & 15.26 \\
\hline & $\mathrm{Ni}$ & 6.43 & 7.48 & 5.82 \\
\hline & Mo & - & 0.46 & 1.38 \\
\hline & $\mathrm{Fe}$ & 8.66 & 55.70 & 76.87 \\
\hline & $\mathrm{Si}$ & - & 0.64 & 0.69 \\
\hline & $\mathrm{C}$ & 9.96 & 7.19 & - \\
\hline
\end{tabular}

from the alloying process. The crystalline columns, arranged along the heat exchange direction, were observed. Contact of a layer after the alloying with the core material led to formation of a transient zone, in which nucleation and an increase in the primary structure crystals were observed.
Figure 7 presents an example of a microstructure that was obtained by the surface alloying for the SSSs. Observations were made using a scanning electron microscope.

Table 6 presents the chemical composition for the surface layers in the SSSs after alloying at a current 


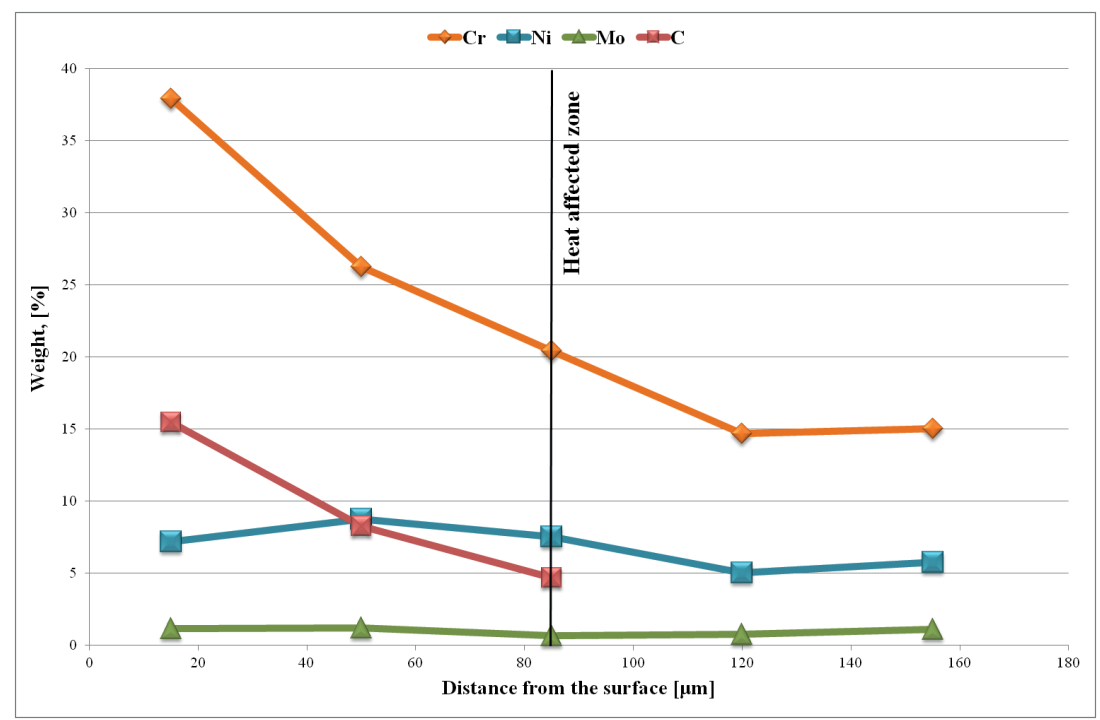

Figure 8 Linear chemical composition analysis for sample 2 after alloying at current intensity $30 \mathrm{~A}$

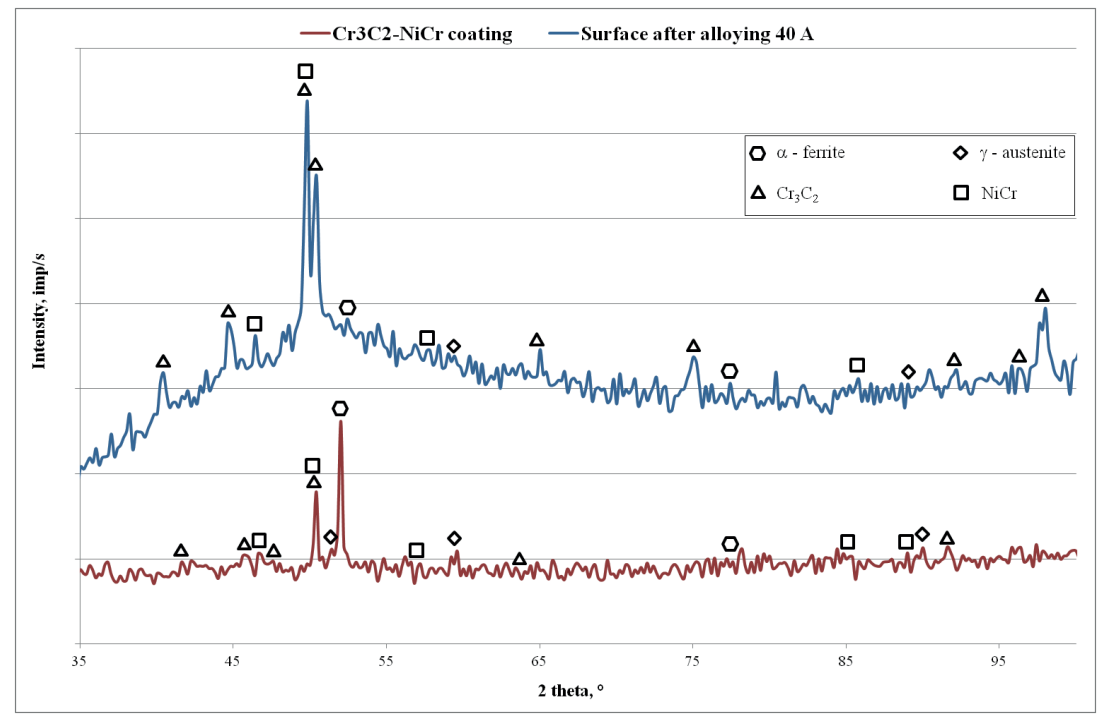

Figure 9 Diffractograms of sample 3 with $\mathrm{Cr}_{3} \mathrm{C}_{2}$-NiCr coating after alloying (40 A)

intensity of 30 A using the GTAW method. The main purpose of this analysis was to compare the presence of selected elements in the areas studied after the surface treatment. Analysis allowed for determination of the migrating alloying elements and thus observation of diffusion occurring in the alloying process. Furthermore, homogeneity of the chemical composition was determined in the obtained surface layers. Analysis of changes in the content of elements showed migration of the diffusing elements (i.e. chromium, nickel). Diffusion occurred between the ferritic and austenitic phases. An intermediate zone was formed as a result of nickel dispersion in austenite. All the samples used in the study showed different contents of the alloying elements.

Figure 8 shows results of the linear analysis of the chemical composition for sample 2 after the GTAW alloying at a current intensity of $30 \mathrm{~A}$. Linear chemical analysis was carried out so that it was possible to present distribution of selected elements vs. distance from the surface, taking into account the modified alloy zone, heat-affected zone and native material. Diffusion of chromium to ferrite and nickel to austenite was confirmed. Consequently, formation of the phase transformations on the boundary of the analysed areas was observed.

The X-ray phase analysis was performed to identify the phase composition on the alloyed surface layer. Figure 9 presents identification of the phase composition for sample 3 with a $\mathrm{Cr}_{3} \mathrm{C}_{2}$-NiCr coating and after the alloying process (40A). The phase analysis for individual specimens revealed the presence of austenitic and ferritic phases, which was proportional to the contents of the powders used.

Phases, obtained during the phase composition analysis of the SSSs, are shown in Table 7. The peak intensities obtained on the diffractogram depend on the content of individual phases in the SSSs.

To analyse the geometric structure, profilometric tests were carried out and the profiles, yielding roughness parameters of steel surface layers, were obtained. Table 
Table 7 Results of the phase composition analysis

\begin{tabular}{ccc}
\hline Phases & Cell & Cell parameters \\
\hline $\mathrm{Cr}_{3} \mathrm{C}_{2}$ & orthorhombic & $\mathrm{a}=0.55 \mathrm{~nm}, \mathrm{~b}=1.14 \mathrm{~nm}, \mathrm{c}=0.28 \mathrm{~nm}$, \\
$\mathrm{NiCr}$ & cubic & $\alpha=\beta=\gamma=90^{\circ}$ \\
& & $\mathrm{a}=\mathrm{b}=\mathrm{c}=0.45 \mathrm{~nm}$, \\
$\alpha$-ferritic & cubic & $\alpha=\beta=\gamma=90^{\circ}$ \\
& & $\mathrm{a}=\mathrm{b}=\mathrm{c}=0.28 \mathrm{~nm}$, \\
$\gamma$ - austenite & cubic & $\alpha=\beta=\gamma=90^{\circ}$ \\
& & $\mathrm{a}=\mathrm{b}=\mathrm{c}=0.35 \mathrm{~nm}$, \\
& $\alpha=\beta=\gamma=90^{\circ}$ \\
\hline
\end{tabular}

Table 8 Roughness parameters of the analysed samples

\begin{tabular}{|c|c|c|c|c|}
\hline \multirow{2}{*}{ Series of samples } & \multirow{2}{*}{ Current intensity (A) } & \multicolumn{3}{|c|}{ Roughness parameter $[\mu \mathrm{m}]$} \\
\hline & & $\mathrm{R}_{\mathrm{a}}$ & $\mathrm{R}_{\mathrm{z}}$ & $\mathrm{R}_{\max }$ \\
\hline \multicolumn{2}{|c|}{$\mathrm{Cr}_{3} \mathrm{C}_{2}-\mathrm{NiCr}$ coating } & $4.79 \pm 0.45$ & $27.35 \pm 3.35$ & $32.28 \pm 0.48$ \\
\hline \multirow{2}{*}{1} & 30 & $3.73 \pm 0.01$ & $22.94 \pm 0.51$ & $31.98 \pm 0.31$ \\
\hline & 40 & $3.51 \pm 0.28$ & $20.93 \pm 0.09$ & $30.29 \pm 0.47$ \\
\hline \multirow{2}{*}{2} & 30 & $3.95 \pm 0.19$ & $22.24 \pm 0.71$ & $31.12 \pm 0.62$ \\
\hline & 40 & $3.73 \pm 0.18$ & $22.45 \pm 0.38$ & $33.06 \pm 0.80$ \\
\hline \multirow{2}{*}{3} & 30 & $3.78 \pm 0.29$ & $21.60 \pm 0.70$ & $28.92 \pm 0.34$ \\
\hline & 40 & $3.40 \pm 0.37$ & $24.88 \pm 0.06$ & $36.06 \pm 0.55$ \\
\hline
\end{tabular}

Table 9 Hardness measurements of specimens (AZ - alloying zone, HAZ - heat affected zone, NM - native material)

\begin{tabular}{cccc}
\hline \multirow{2}{*}{ Series of samples } & Current intensity (A) & Hardness (HV 0.1) & HAZ \\
\cline { 3 - 4 } 1 & 30 & $283.67 \pm 0.98$ & $231.00 \pm 0.10$ \\
& 40 & $347.00 \pm 0.05$ & $226.33 \pm 0.33$ \\
2 & 30 & $388.00 \pm 0.30$ & $272.00 \pm 0.33$ \\
& 40 & $443.00 \pm 0.28$ & $277.00 \pm 0.31$ \\
3 & 30 & $686.50 \pm 0.50$ & $453.00 \pm 0.01$ \\
& 40 & $602.00 \pm 0.02$ & $354.00 \pm 0.12$ \\
\hline
\end{tabular}

8 illustrates the roughness parameters for the $\mathrm{Cr}_{3} \mathrm{C}_{2}-\mathrm{NiCr}$ coating and surface of the SSSs after alloying. The following parameters were selected for analysis: $R_{a}, R_{z}$ and $R_{\max }$

Considering the first stage of modification, i.e. deposition of the $\mathrm{Cr}_{3} \mathrm{C}_{2}$ - $\mathrm{NiCr}$ coating, the roughness parameter on the surface of sinters was measured $\left(R_{a}=\right.$ $4.79 \mu \mathrm{m})$. Application of the GTAW method for the alloying surface treatment led to improvement in roughness. The parameters obtained (e.g. $R_{a}, R_{z}$ and $R_{\max }$ ) are lower than before the modifications. Along with an increase in the current intensity, the sintered surface was smoothed (lower values of $R_{a}$ ). This is associated with the linear energy of the arc applied to the steel surface during the alloying.

Mechanical properties were evaluated based on hardness measurements by the Vickers method. Table 9 presents hardness of the $\mathrm{Cr}_{3} \mathrm{C}_{2}$-NiCr coating, alloying zone, heat-affected zone and native material obtained after alloying at different current intensities. Three measurements were performed, and their means are shown in the table below.
The proposed modification with the $\mathrm{Cr}_{3} \mathrm{C}_{2}-\mathrm{NiCr}$ coating and GTAW alloying led to homogenization of the microstructure, as confirmed by the hardness tests. Contents of individual phases had a direct effect on the mechanical properties of sinters. Formation of the $\mathrm{Cr}_{3} \mathrm{C}_{2}$ $\mathrm{NiCr}$ coating dramatically improves the strength properties of the SSSs. Furthermore, analysis of hardness revealed that the GTAW method led to improvement in mechanical properties of the samples.

The scratch test under the constant load was conducted to determine the coefficient of friction (COF) and wear resistance. Table 10 shows the friction coefficients for the SSSs, as obtained during the scratch test. Figure 10 shows a diagram of the normal load and friction for sample 1 after alloying (at $40 \mathrm{~A}$ ) obtained after the scratch test.

Resistance to friction depends on many factors. Scratch tests confirmed that the applied surface treatment reduces the coefficient of friction of sintered steels (SSS) modified with chromium carbide. This coefficient depends on the current-voltage parameters used during the remelting. 
Table 10 Coefficients of friction for the analysed samples (AZ - alloying zone, NM - native material)

\begin{tabular}{|c|c|c|c|}
\hline \multirow{2}{*}{ Series of samples } & \multirow{2}{*}{ Current intensity (A) } & \multicolumn{2}{|c|}{ Coefficient of friction } \\
\hline & & $\mathrm{AZ}$ & NM \\
\hline \multirow{2}{*}{1} & 30 & 0.18 & \multirow{2}{*}{0.14} \\
\hline & 40 & 0.14 & \\
\hline \multirow{2}{*}{2} & 30 & 0.15 & \multirow{2}{*}{0.13} \\
\hline & 40 & 0.12 & \\
\hline \multirow{2}{*}{3} & 30 & 0.17 & \multirow{2}{*}{0.15} \\
\hline & 40 & 0.14 & \\
\hline \multicolumn{2}{|c|}{$\mathrm{Cr}_{3} \mathrm{C}_{2}-\mathrm{NiCr}$ coating } & \multicolumn{2}{|c|}{0.30} \\
\hline
\end{tabular}

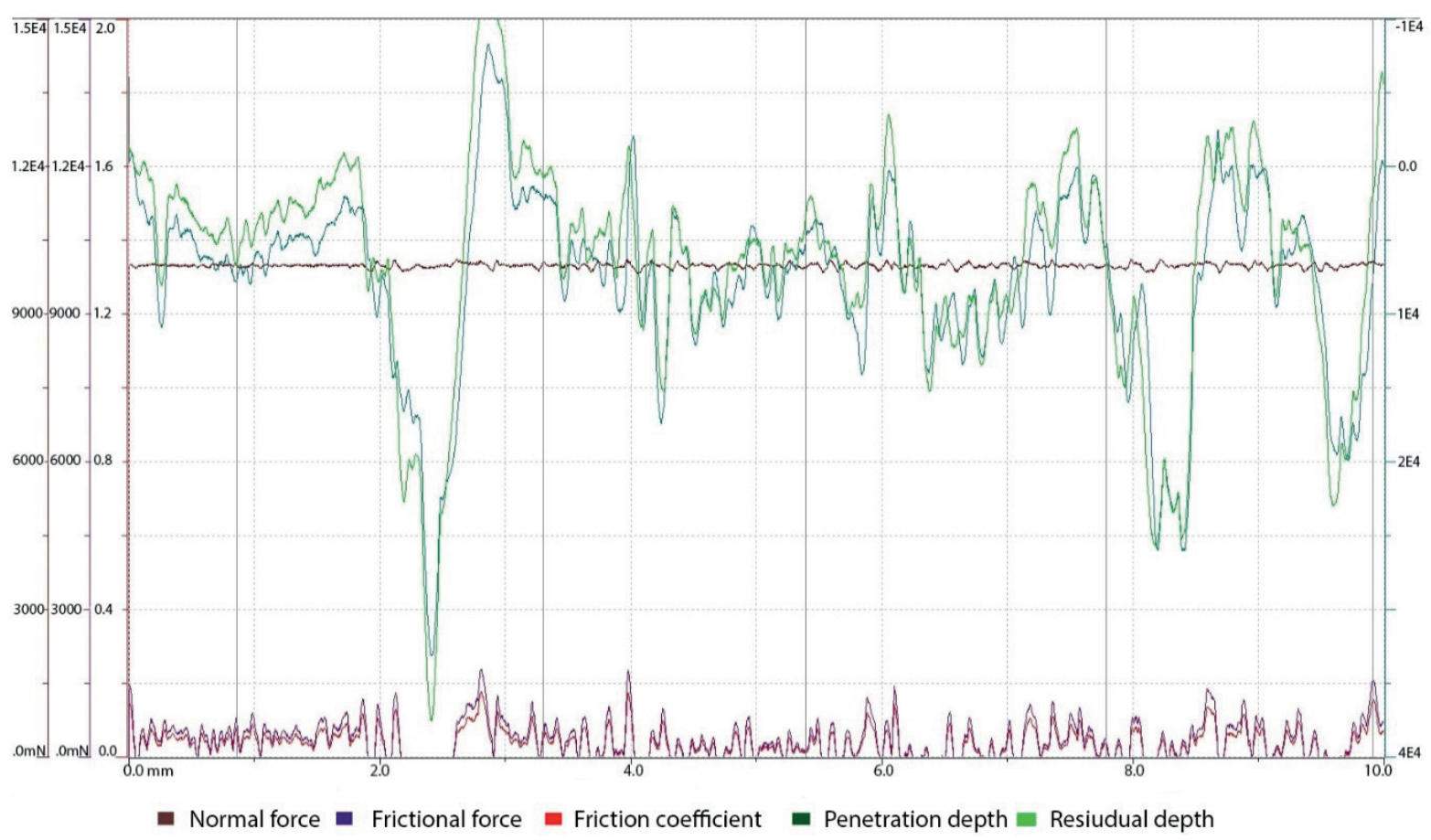

Figure 10 The effect of alloying (40A) on coefficient of friction for sample 1

Based on results, it can be concluded that the greater the resistance to abrasive wear, the lower the coefficient of friction. The method of surface modification, discussed in the present study, allowed for improvement of the mechanical properties of the samples studied.

\section{Conclusions}

Sintered stainless steels are mainly used in the automotive industry, which is open to new material solutions to meet the growing needs and expectations of customers, e.g. in reducing mass of details, especially in electric cars [34]. This is followed by proposals of material engineers aimed to continuously modify and improve the materials used. Modification of the surface layer of the SSSs, proposed in this paper, represents a proposal to apply the two-stage surface treatment (spraying and remelting) to improve the functional properties of the parts.
The authors of the paper proposed the modification of the surface of the sintered two-phase steels (AISI 316L and AISI $409 \mathrm{~L}$ ) by introducing $\mathrm{Cr}_{3} \mathrm{C}_{2}$ carbide into the surface layer of steel. The most important problem was to choose melting parameters to ensure the change in the physical and chemical properties of the steel surface. Results presented in this study are part of advanced research conducted by the authors $[6,12,26,31,33]$.

Alloying the surfaces of sintered stainless steels yielded a gradual change in the chemical composition of the surface layer vs. distance from the surface of the modified materials. The depth of the modified zone was on average $100 \mu \mathrm{m}$ for samples remelted at 30A and $130 \mu \mathrm{m}$ for those remelted at 40A. The change in the chemical composition and internal stresses that occur in the remelted material resulted in improved strength properties expressed in hardness (a twofold increase in hardness of the modified layer was obtained compared to the unmodified material). Use of the concentrated energy source (GTAW method) 
and appropriate choice of melting parameters resulted in reduction in the specific surface area of steel compared to the $\mathrm{Cr}_{3} \mathrm{C}_{2}$ coating. This result is very important from the standpoint of abrasive wear resistance and corrosion resistance of these materials. An increase in abrasive wear resistance of the modified steels was confirmed by the analysis of the coefficient of friction (during the scratch test). As the current-voltage parameters, used in the remelting process, increased, the coefficient of friction decreased compared to the coefficient of friction of the carbide coating, which can be associated with a change in chemical composition and hardness of the modified layer.

\section{References}

[1] SHOJAATI, M., BEIDOKHTI, B. Characterization of AISI 304/AISI 409 stainless steel joints using different filler materials. Construction and Building Materials[online]. 2017, 147, p. 608-615. ISSN 0950-0618. Available from: https:// doi.org/10.1016/j.conbuildmat.2017.04.185

[2] FALKOWSKA A., SEWERYN A., TOMCZYK A. Fatigue life and strength of 316L sintered steel of varying porosity. International Journal of Fatigue[online]. 2018, 111, p. 161-176.ISSN 0142-1123. Available from: https://doi. org/10.1016/j.ijfatigue.2018.02.023

[3] VICEN, M., BRONCEK, J., NOVY, F. Investigation of tribological properties of carbonx coating deposited on $100 \mathrm{Cr6}$ steel. Production Engineering Archives[online]. 2019, 25(25), p. 52-55. ISSN 2353-5156, eISSN 2353-7779. Available from: https://doi.org/10.30657/pea.2019.25.10

[4] SARJAS, H., KULU, P., JUHANI, K., VILJUS, M., MATIKAINEN, V., VUORISTO, P. Wear resistance of HVOF sprayed coatings from mechanically activated thermally synthesized $\mathrm{Cr}_{3} \mathrm{C}_{2}-\mathrm{Ni}$ spray powder. Proceedings of the Estonian Academy of Sciences[online]. 2016, 65(2), p. 101-106. ISSN 1736-6064, eISSN 1736-7530. Available from: https://doi. org/10.3176/proc.2016.2.10

[5] KURGAN, N. Effects of sintering atmosphere on microstructure and mechanical property of sintered powder metallurgy 316L stainless steel. Materials and Design [online]. 2013, 52, p. 995-998. ISSN 0261-3069. Available from: https://doi.org/10.1016/j.matdes.2013.06.035

[6] DUDEK, A., LISIECKA, B., ULEWICZ,R. The Influence of alloying method on the microstructure and properties of the PM stainless steel. In: 25th Anniversary International Conference on Metallurgy and Materials, Metal 2016: proceedings. 2016, p. 1045-1050.

[7] LIPINSKI, T. Corrosion of the 1.4362 duplex stainless steel in a nitric acid environment at $333 \mathrm{~K}$. Acta Physica Polonica $A$ [online]. 2019, 135(2), p. 203-206. ISSN 0587-4246. Available from: https://doi.org/10.12693/APhysPolA.135.203

[8] ULEWICZ, R., MAZUR, M. Economic aspects of robotization of production processes by example of a car semitrailers manufacturer. Manufacturing Technology[online]. 2019, 19(6), p. 1054-1059. ISSN 1213-2489. Available from: https://doi.org/10.21062/ujep/417.2019/a/1213-2489/MT/19/6/1054

[9] GODWIN, G., JULYES JAISINGH, S., SHUNMUGA PRIYAN, M. Tribological and corrosion behavior studies on $\mathrm{Cr}_{3} \mathrm{C}_{2}-$ NiCr powder coating by HVOF spray method - a review. Journal of Materials Science and Surface Engineering [online]. 2017, 5(2), p.537-543. ISSN 2348-8956. Available from: https://doi.org/10.jmsse/2348-8956/5-2.4

[10] KORKMAS, K. Investigation and characterization of electro spark deposited chromium carbide-based coating on the steel. Surface and Coatings Technology [online]. 2015, 272, p. 1-7. ISSN 0257-8972. Available from: https://doi.org/10.1016/j.surfcoat.2015.04.033

[11] DU, J., FANG, L., LI, Y.-L., WANG, L.-M., LU, H.-Y., RAN, X.-J., ZHANG, X.-Y. Influences of plasma arc remelting on microstructure and service performance of $\mathrm{Cr}_{3} \mathrm{C}_{2}-\mathrm{NiCr} / \mathrm{NiCrAl}$ composite coating. Surface and Coatings Technology[online]. 2019, 369, p. 16-30. ISSN 0257-8972. Available from: https://doi.org/10.1016/j.surfcoat.2019.04.037

[12] LISIECKA, B., DUDEK, A. The surface treatment of sintered stainless steel. Terotechnology Materials Research Proceedings [online]. 2017, 5, p. 148-153. ISSN 2474-3941, eISSN 2474-395X. Available from: http://dx.doi.org/10.21741/9781945291814-26

[13] MATIKAinen, V., BOlElli, G., KOIVUluOTO, H., SASSATElli, P., LUSVARGHI, L., VUORISTO, P. Sliding wear behaviour of HVOF and HVAF sprayed $\mathrm{Cr}_{3} \mathrm{C}_{2}$-based coatings. Wear [online]. 2017, 388-389, p. 57-71. ISSN 0043-1648. Available from: https://doi.org/10.1016/j.wear.2017.04.001

[14] JANKA, L., BERGER, L.M., NORPOTH, J., TRACHE, R., THIELE, S., TOMASTIK, CH. MATIKAINEN, V., VUORISTO, P. Improving the high temperature abrasion resistance of thermally sprayed $\mathrm{Cr}_{3} \mathrm{C}_{2}-\mathrm{NiCr}$ coatings by WC addition. Surface and Coatings Technology [online]. 2018, 337, p. 296-305. ISSN 0257-8972. Available from: https://doi.org/10.1016/j.surfcoat.2018.01.035

[15] BRUPBACHER, M.C., ZHANG, D., BUCHTA, W.M., GRAYBEAL, M. L., RHIM, Y.-R., NAGLE, D. C., SPICER, J. A. Synthesis and characterization of binder-free $\mathrm{Cr}_{3} \mathrm{C}_{2}$ coatings on nickel-based alloys for molten fluoride salt corrosion resistance. Journal of Nuclear Materials [online]. 2015, 461, p. 215-220. ISSN 0022-3115. Available from: https://doi.org/10.1016/j.jnucmat.2015.03.017 
[16] ROMERO, J., LOUSA, A., MARINEZ, E., ESTEVE, J. Nanometric chromium y chromium carbide multilayers for tribological applications. Surface and Coatings Technology [online]. 2003, 163-164, p. 392-397. ISSN 0257-8972. Available from: https://doi.org/10.1016/S0257-8972(02)00634-5

[17] SCHWANEKAMP, T., MARGINEAN, G., REUBER, M. Laser beam melting of $\mathrm{Cr}_{3} \mathrm{C}_{2}$-NiCr. International Jourmal of Refractory Metals and Hard Materials [online]. 2019, 85, p. 105069. ISSN 0263-4368. Available from: https://doi.org/10.1016/j.jjrmhm.2019.105069

[18] BOBZIN, K., ZHAO, L., OTE, M., KONIGSTEIN, T., STEEGER, M. Impact wear of an HVOF-sprayed $\mathrm{Cr}_{3} \mathrm{C}_{2}-\mathrm{NiCr}$ coating. International Journal of Refractory Metals and Hard Materials [online]. 2018, 70, p. 191-196. ISSN 0263-4368. Available from: https://doi.org/10.1016/j.ijrmhm.2017.10.011

[19] ZHAO, Z., ZHENG, H., WANG, Y., MAO, S., NIU, J., CHEN, Y., SHANG, M. Synthesis of chromium carbide $\left(\mathrm{Cr}_{3} \mathrm{C}_{2}\right)$ nanopowders by the carbonization of the precursor. International Journal of Refractory Metals and Hard Materials [online]. 2011, 29(5), p. 614-617. ISSN 0263-4368. Available from: https://doi.org/10.1016/j.ijrmhm.2011.04.007

[20] ROBERTSON, A.L., WHITE, K.W. Microscale fracture mechanisms of a $\mathrm{Cr}_{3} \mathrm{C}_{2}$-NiCr HVOF coating. Materials Science and Engineering: A [online]. 2017, 688, p. 62-69. ISSN 0921-5093. Available from: https://doi.org/10.1016/j.msea.2017.01.097

[21] MYALSKA, H., MOSKAL, G., SZYMANSKI, K. Microstructure and properties of WC-Co coatings, modified by submicrocrystalline carbides, obtained by different methods of high velocity spray processes. Surface and Coatings Technology [online] 2014, 260, p. 303-309. ISSN 0257-8972. Available from: https://doi.org/10.1016/j.surfcoat.2014.07.097

[22] MATTHEWS, S., BHAGVANDAS, M., BERGER, L.M. Creation of modified $\mathrm{Cr}_{3} \mathrm{C}_{2}$-NiCr hard metal coating microstructures through novel processing. Jourmal of Alloys and Compounds [online]. 2020, 824, p. 153868. ISSN 0925-8388. Available from: https://doi.org/10.1016/j.jallcom.2020.153868

[23] WU, H., KONG, D. Effects of laser power on friction-wear performances of laser thermal sprayed $\mathrm{Cr}_{3} \mathrm{C}_{2}-\mathrm{NiCr}_{\mathrm{Composite}}$ coatings at elevated temperatures. Optics and Laser Technology [online]. 2019, 117, p. 227-238. ISSN 0030-3992. Available from: https://doi.org/10.1016/j.optlastec.2019.04.022

[24] OKE, S.R., IGE, O.O., FALODUN, O.E., OKORO, A. M., MPHAHLELE, M. R., OLUBAMBI, P. A. Powder metallurgy of stainless steels and composites: a review of mechanical alloying and Spark plasma sintering. The International Journal of Advanced Manufacturing Technology [online]. 2019, 102, p. 3271-3290. ISSN 0268-3768, eISSN $1433-301$. Available from: https://doi.org/10.1007/s00170-019-03400-2

[25] LIU, L., XU, H., XIAO, J., WEI, X., ZHANG, G., ZHANG, CH. Effect of heat treatment on structure and property evolutions of atmospheric plasma sprayed NiCrBSi coatings. Surface and Coatings Technology [online]. 2017, 325, p. 548-554. ISSN 0257-8972. Available from: https://doi.org/10.1016/j.surfcoat.2017.07.011

[26] LISIECKA, B., DUDEK, A. Characterization of the $\mathrm{Cr}_{3} \mathrm{C}_{2}-\mathrm{NiAl}$ coatings on sintered duplex stainless steels. Inzynieria Materialowa Materials Engineering [online]. 2018, 39(3), p. 100-104. ISSN 0208-6247, eISSN 2449-9889. Available from: https://doi.org/10.15199/28.2018.3.2

[27] MOSKAL, G. Thermal barrier coatings: characteristics of microstructure and properties, generation and directions of development of bond. Journal of Achievements in Materials and Manufacturing Engineering. 2009, 37(2), p.323-331. ISSN 1734-8412.

[28] PAULRAJ, P., GARG, R. Effect of welding parameters on pitting behaviour of GTAW of DSS and super DSS weldments. Engineering Science and Technology, an International Journal [online]. 2016, 19(2), p. 1076-1083. ISSN 2215-0986. Available from: https://doi.org/10.1016/j.jestch.2016.01.013

[29] MD IDRISS, A.N., MRIDHA, S., BAKER, T.N. Laser and GTAW torch processing of Fe-Cr-B coatings on steel Part I - melt features. Materials Science and Technology [online]. 2014, 30(10), p. 1209-1213. ISSN 0267-0836, eISSN $1743-2847$. Available from: https://doi.org/10.1179/1743284713Y.0000000435

[30] TSENG, K.H., WANG, N.S. Research on bead width and penetration depth of multicomponent flux-aided arc welding of grade 316L stainless steel. Powder Technology [online]. 2017, 311, p. 514-521. ISSN 0032-5910. Available from: https://doi.org/10.1016/j.powtec.2017.02.005

[31] LISIECKA, B., DUDEK, A. Modification of the surface layer of sintered duplex stainless steels through alloying using the GTAW method. Tribologia. 2018, 2, p.81-88. ISSN 0208-7774.

[32] ZOU, Y., UEJI, R., FUJII, H. Mechanical properties of advanced active-TIG welded duplex stainless steel and ferrite steel. Materials Science and Engineering: A [online]. 2015, 620, p. 140-148. ISSN 0921-5093. Available from: https://doi.org/10.1016/j.msea.2014.10.006

[33] LISIECKA, B., DUDEK, A. Microstructure and friction parameters of the surface layer of sintered stainless steels. Tribologia. 2019, 4, p. 41-51. ISSN 0208-7774.

[34] LISEC, A., LISEC, K., OBRECHT, M. Cost and safety aspects of using electric and hybrid vehicles in local food supply chain. Production Engineering Archives [online]. 2019, 25(25), p. 35-38. ISSN 2353-5156, eISSN 2353-7779. Available from: https://doi.org/10.30657/pea.2019.25.06 